\title{
PERAN MEDIA SOSIAL BAGI SUAMI ISTRI DALAM MENJALANI HUBUNGAN PERNIKAHAN JARAK JAUH
}

\author{
Maulidia Mulyani \\ UIN Sunan Kalijaga Yogyakarta. E-mail: \\ maulidiamulyani@gmail.com
}

\begin{abstract}
In the present time the impact of technological progress can be felt in many aspects of life, including marriage. The progress of the development of communication technology has made it easy to communicate specifically for married couples who are undergoing long-distance marital relationships, so that the relationship is maintained and harmonious. Social media is now used as a tool for communication, for example Whats App, Line, Facebook, or Instagram. All of those media are used because of their speed in conveying messages, so that long-distance couples can still communicate well and quickly. In a marital relationship, of course, there are fulfillments of rights and obligations. These fulfillments can still be fulfilled through social media, but they are not as maximized as when dealing directly.
\end{abstract}

Keywords: Social Media, Marriage, Long Distance Relationships

\begin{abstract}
Abstrak: Di masa kini dampak kemajuan teknologi dapat dirasakan dalam banyak aspek kehidupan, termasuk perkawinan. Kemajuan perkembangan teknologi komunikasi telah memberikan kemudahan dalam berkomunikasi khususunya bagi pasangan suami-istri yang sedang menjalani hubungan pernikahan jarak jauh agar hubungan tersebut tetap terjaga dan harmonis. Media sosial kini dijadikan sebagai alat untuk berkomunikasi secara instan misal whatsapp, line, facebook, atau instagram. Semua itu digunakan karena kecepatannya dalam menyampaikan pesan sehingga pasangan suami-istri jarak jauh pun tetap bisa berkomunikasi dengan baik dan cepat. Dalam hubungan suami-istri tentu terdapat hak dan kewajiban yang harus dipenuhi. Pemenuhan tersebut tetap bisa dilakukan melalui media sosial meskipun memang tidak semaksimal seperti ketika berhubungan secara langsung.
\end{abstract}

Kata Kunci: media sosial, pernikahan, hubungan jarak jauh.

\section{Pendahuluan}

Dalam salah satu postulatnya, William C. Schutz menyatakan bahwa setiap manusia memiliki tiga kebutuhan antar pribadi yang disebut dengan inklusif, kontrol dan afeksi. Dasarnya adalah bahwa 
manusia pasti membutuhkan orang lain sebagai makhluk sosial. Berikut bunyi postulat yang dimaksud:

"Interpersonals needs can be divided into three categories, they are inclusion, control and affection. Inclusion refers to the need to maintain a satisfactory relationship with others and to have enough involvement and belongingness control is associated with the need for influence and power and affection refers to the need for friendship, closeness, and love." 1

"Kebutuhan antar pribadi dapat dibagi menjadi tiga kategori, yaitu inklusi, kontrol dan kasih sayang. Inklusi mengacu pada kebutuhan untuk mempertahankan hubungan yang memuaskan dengan orang lain dan untuk memiliki keterlibatan yang cukup, kontrol terkait dengan kebutuhan atas pengaruh dan kekuatan serta kasih sayang mengacu pada kebutuhan untuk persahabatan, kedekatan, dan cinta."

Mengapa riset ini dilakukan yaitu berangkat dari salah satu fenomena yang berkembang di masyarakat antara suami dan istri saling bekerja sama dalam memenuhi kebutuhan berumah tangga. Hal ini yang menyebabkan pola berkeluarga menjadi berbeda, yaitu salah satu suami atau istri harus meninggalkan rumah dan anakanaknya demi menjalankan karirnya. Dalam hal ini, tentu keduanya harus tetap fokus dan saling menjalankan kewajibannya masingmasing bersamaan dengan karir dan berumah tangga.

Pada masa kini, pasangan suami-istri yang menjalani hubungan jarak jauh tidak terlalu kesusahan untuk menjalin komunikasi dengan adanya media sosial yang memiliki peranan penting dan membantu dalam membangun komunikasi di antara keduanya. Media sosial merupakan salah satu bentuk perkembangan teknologi pengiriman pesan yang cepat dan efiesien. Beberapa orang menggunakan media sosial agar tetap dapat terhubung dan terkoneksi, sekaligus membantu memenuhi kebutuhan berkomunikasi antara makhluk sosial. Media sosial kini sudah menjadi bagian dari kehidupan masyarakat sehingga penting bagi seseorang untuk menggunakannya.

1 S. Ramaraju, "The Interpersonal Underworld", Psychological Perspectives On Interpersonal Communication, Vol. III, No. 4 (Oktober, 2012), 71. 
Hampir semua aspek kehidupan bisa tereskspose ke dalam ranah media sosial, termasuk perkawinan. Hal ini tanpa terasa telah menjadi bagian dari kehidupan yang dominan di tengah masyarakat. Segala emosi bisa dicurahkan ke dalam platform media sosial, begitu juga dalam menjalin komunikasi melalui interaksi dalam chatting, video call, maupun free call. Oleh karenanya, kini pasangan suami-istri yang berhubungan jarak jauh tidak merasa kesusahan dalam menjalin hubungan dengan pasangannya maupun dengan anak-anaknya serta dalam hal pemenuhan kewajiban dan hak yang dimiliki oleh keduanya.

\section{Media Sosial: Menjalin Komunikasi Pasangan Jarak Jauh}

Dalam perkembangannya di dunia modern, perkembangan teknologi kini semakin canggih dan mampu memenuhi kebutuhan berkomunikasi untuk manusia. Media sosial sebagai alat untuk menjalin komunikasi bagi siapapun yang ingin tetap tersambung meski dalam keadaan berjauhan. Mengambil keputusan berhubungan jarak jauh bukanlah suatu yang mudah karena berbagai permasalahan tentunya akan dihadapi bagi pasangan yang menjalankan hubungan jarak jauh, terlebih ketika hidup di masa di mana teknologi pesan belum secepat di masa kini.

Namun seiring berjalannya waktu, menjalin hubungan jarak jauh di masa kini tidaklah terlalu sukar, seperti halnya di masa lalu ketika pesan hanya bisa disampaikan melalui surat-menyurat dengan waktu penyampaian yang relatif lama atau via telepon yang membutuhkan biaya begitu besar, terlebih ketika pasangan suamiistri tersebut menjalin hubungan antar negara.

Seorang suami ataupun istri tidak begitu mengalami kesusahan ketika menjalani hubungan jarak jauh, terlebih ketika mereka hanya fokus terhadap pasangannya dan pekerjaanya, berbeda dengan halnya ketika seorang pasangan tersebut menjalani hubungan jarak jauh dan dalam kondisi memiliki anak, hal ini dapat diketahui melalui beberapa hasil wawancara terhadap suami atau istri yang sedang menjalani hubungan jarak jauh. 
Data Koresponden 1

\begin{tabular}{|l|l|l|}
\hline \multicolumn{1}{|c|}{ Keterangan } & \multicolumn{1}{c|}{ Suami } & \multicolumn{1}{c|}{ Istri } \\
\hline Inisial & IA & YS \\
\hline Usia & 24 & 24 \\
\hline Agama & Islam & Islam \\
\hline Asal & Kalimantan & Solo \\
\hline Pendidikan Terakhir & S1 & S2 \\
\hline Pekerjaan & Pengusaha & Mahasiswa \\
\hline Tempat Bekerja & Yogyakarta & Ceko \\
\hline Status & Menikah & Menikah \\
\hline Lama Menikah & 8 Bulan & 8 Bulan \\
\hline Jumlah Anak & Belum & Belum \\
\hline
\end{tabular}

Koresponden 1 merupakan seorang suami berinsial IA yang berdomisili di Yogyakarta dan menjalakan hubungan jarak jauh dengan istrinya yang berinisial YS yang di Ceko yang berstatus sebagai mahasiswa. IA menceritakan pengalamannya berhubungan jarak jauh dengan media sosial sebagai berikut:

"Media sosial sangat membantu dalam menjalani hubungan LDR. Topik finansial biasanya kami bahas, tentang bagaimana rencana ke depan untuk mengatur pemasukan dan pengeluaran, bahas masalah sumber dana dari mana. Tak lupa persoalan masalah keluarga, gimana kami bisa bantu anggota keluarga yang lain terutama orang tua, intinya kunci semua masalah ada di komunikasi kami yang tetap dijaga dengan baik walau LDR. Saya pun juga sering menanyakan kabar istri, sedang berkegiatan apa? atau menanyakan apakah ada yang bisa dibantu terkait hal-hal perkuliahan.

"Saya merasa, chat via media sosial ini membuat saya semakin dekat, dan justru malah membuat saya penasaran dan sering intens bertanya satu sama lain. Meski saya di Indonesia dan Istri di Ceko, tentu perbedaan jam terkadang menjadi masalah, tapi karena media sosial terutama chat line ini cukup fleksibel dan mudah digunakan kapan saja dan di mana saja, tentunya ini sangat membantu komunikasi kami."

"Kami sering, setidaknya seminggu dua kali untuk video call menggunakan line. Biasanya istri video call saya, saat sedang 
memasak atau kadang saat di kampus disela-sela istri mengerjakan tugas-tugas kuliahnya."2

Tentunya media sosial memiliki banyak macam dan ragam, namun IA merasa bahwa media chatting via line lebih menyenangkan, karena line memiliki beragam fitur terutama banyaknya stiker yang mampu mengekspresikan diri meski dalam keadaan jauh.

"Line bagi saya lebih menyenangkan daripada Whatsapp atau BBM. Line menyediakan banyak stiker atau stiker bergerak, jadinya chat yang dihasilkan tidak terlalu membosankan, selain chat, line juga bisa untuk video call atau pun telepon dan semua ini hanya pakai wifi. Hubungan jarak jauh tidak terlalu berat diongkos dan tetap menjalani komunikasi dengan baik."

Koresponden IA juga menceritakan tentang peranan antara suami dan istri agar dapat terlaksana dengan baik dan apabila ada masalah dalam rumah tangga, masalah tersebut bisa teratasi dengan maksimal.

"Sebetulnya kami satu sama lain kan tetap bekerja sama dan saling mengisi. Ya tetap berjalan walau memang tidak maksimal seperti rumah tangga yang tidak LDR karena gimanapun komunikasi non verbal, non virtual itu lebih punya pengaruh yang kuat."

"Saya dan istri selalu berkomitmen dan membuat kesepakatan, misalnya apabila ada masalah kecil atau salah paham, salah satu dari kami harus ada yang telepon, agar persoalan itu cepat diselesaikan dan tidak menumpuk di belakang."

Komunikasi harus lebih sering dilakukan ketika sudah memiliki anak meski dalam hubungan jarak jauh. Dalam hal ini, IA memberikan pendapatnya jika suatu saat dianugrahi anak, anak tersebut haruslah dalam lingkup kasih sayang kedua orang tua serta dibesarkan oleh kedua orang tuanya.

"Idealnya anak ini dibesarkan dengan peran 2 orangtuanya, tapi kalau misal kondisi memaksa demikian pastinya saya kesulitan banget, nah makanya saya memilih untuk tinggal dengan keluarga (orangtua) biar nantinya ortu tetap bisa

2 Koresponden IA, Wawancara, Sejak April 2018. 
membantu karena kami tidak mau anak kami nantinya diurus oleh orang lain.“

Data Koresponden 2

\begin{tabular}{|l|l|l|}
\hline \multicolumn{1}{|c|}{ Keterangan } & Suami & \multicolumn{1}{c|}{ Istri } \\
\hline Inisial & F & IS \\
\hline Usia & 33 & 22 \\
\hline Agama & Islam & Islam \\
\hline Asal & Balikpapan & Balikpapan \\
\hline Pendidikan Terakhir & S1 & S1 \\
\hline Pekerjaan & Wirausaha & Mahasiswa \\
\hline Tempat Bekerja & Kalimantan & Kalimantan \\
\hline Status & Menikah & Menikah \\
\hline Lama Menikah & 4 Tahun & 4 Tahun \\
\hline Jumlah Anak & Belum & Belum \\
\hline
\end{tabular}

Selain koresponden 1 terdapat koresponden 2 yang juga menceritakan pengalamannya saat menjalani hubungan jarak jauh. Koresponden 2 berinisial IS seorang istri yang berdomisili di Balikpapan, sedangkan suaminya berinisial $\mathrm{F}$ juga berdomisili di Balikpapan, namun berbeda wilayah sehingga mereka menjalani hubungan jarak jauh. Hubungan jarak jauh yang mereka pilih ini lantaran suami $\mathrm{F}$ mendapat penempatan pekerjaan di wilayah tersebut, sedangkan istri atau IS sedang mengenyam pendidikan S1 di Balikpapan Pusat. Koresponden 2 bercerita bahwa media sosial mampu membantu hubungan keduanya dalam menjalani hubungan jarak jauh dengan uraian sebagai berikut:

"Sangat membantu sekali, media sosial adalah kemajuan elektronik yang sangat membantu hubungan jarak jauh, apalagi whatsapp, line atau instagram karena kami merasa lebih dekat dan tetap tahu informasi satu sama lain."

"Dari keseluruhan media chat, saya dan suami lebih suka pakai whatsapp daripada line ataupun BBM, whatsapp lebih ringan dan tidak terlalu menguras memori. Meski kami LDRnya tidak terlalu jauh atau sampai pisah pulau, setidaknya media sosial dengan pesan chat ini dapat membantu komunikasi kami dan tarifnya juga murah. Kami berdua cenderung jarang 
menggunakan media telepon di luar dari media sosial, karena jatuhnya ketika menelepon itu lebih mahal, dan tentunya mengeluarkan pulsa lebih banyak, sedangkan kami apabila terlanjur asyik menelepon, tidak bisa hanya diberi waktu 30 menit, paling tidak kami terkadang saling bertelepon hingga 1 jam."

"Topik yang sering kami bahas dalam obrolan kami tentang keseharian. Semacam cerita tentang kegiatan seharian ini apa aja atau hal-hal yang menarik yang dilakukan selama tidak sedang berdekatan. Kadangpun juga bisa timbul masalah karena masalah jarak ini, tapi karena suami lebih dewasa dan usia lebih tua makanya saya yang lebih sering diberi pengertian dan suami tentunya lebih sabar. Tapi di lain sisi kalau hanya via medsos sebenarnya sangat terbatas sekali, tapi setidaknya tetap bisa membantu meski dikit. Lebih puas sih setiap masalah dalam hubungan rumah tangga ini diselesaikan dengan tatap muka, terkadang saya dan suami harus menunggu dulu untuk menyelesaikan beberapa persoalan yang sekiranya rumit. Apabila masalahnya simple, suami saya langsung menelepon saya dengan menggunakan video call, video call ini sangat membantu sekali untuk berkomunikasi dengan saling bertatap muka, namun di lain sisi komunikasi online ini tidaklah semaksimal dengan berkomunikasi langsung."3

Dari kedua koresponden tersebut belum ditemukan perubahan yang signifikan atau memberikan pengaruh lebih terhadap hubungan jarak jauh pasangan suami-istri. Tentunya menjadi lebih berbeda dengan hasil wawancara koresponden ketiga karena pasangan suami-istri ketiga ini telah dianugrahi 2 anak.

Data Koresponden 3

\begin{tabular}{|l|l|l|}
\hline \multicolumn{1}{|c|}{ Keterangan } & \multicolumn{1}{c|}{ Suami } & \multicolumn{1}{c|}{ Istri } \\
\hline Inisial & $\mathrm{P}$ & $\mathrm{AD}$ \\
\hline Usia & 32 & 29 \\
\hline Agama & Islam & Islam \\
\hline
\end{tabular}

3 Koresponden IS, Wawancara, Sejak Mei 2018. 
Maulidia Mulyani: Peran Media Sosial Bagi Suami Istri.....

\begin{tabular}{|l|l|l|}
\hline Asal & Kediri & Kediri \\
\hline Pendidikan Terakhir & S2 & S1 \\
\hline Pekerjaan & PNS & PNS \\
\hline Tempat Bekerja & Sidoarjo & Merauke \\
\hline Status & Menikah & Menikah \\
\hline Lama Menikah & 6 Tahun & 6 Tahun \\
\hline Jumlah Anak & 2 Anak & 2 Anak \\
\hline
\end{tabular}

Koresponden 3 berinisial AD yaitu seorang istri dari PK. AD saat ini bekerja di Merauke sehingga dia pun berdomisili sementara di sana, sedangkan PK suami dari AD dan anak-anaknya kini tinggal di Sidoarjo. Awalnya AD ini bekerja di Surabaya, sehingga AD tetap bisa tinggal serumah dengan anak-anaknya. Pada saat itu, AD memang sering ditugaskan ke luar kota, namun penugasannya hanya beberapa hari saja sehingga $\mathrm{AD}$ tidak merasakan perubahan hubungan jarak jauhnya secara drastis. Saat ini kedua anaknya diasuh oleh suami $\mathrm{AD}$ beserta asisten rumah tangganya. $\mathrm{AD}$ sebagai istri sempat cemas ketika harus menjalani hubungan tersebut, namun sangat membantu terbantu dengan peran media sosial dalam mengatasi komunikasi sebagaimana pemaparannya berikut:

"Media sosial sangat membantu sekali dan saya merasakan hubungan LDR ini tidak terlalu terganggu dengan hal-hal yang ada di media sosial. Di jaman sekarang ini tentunya sangat rumit kalau masih mengandalkan surat menyurat karena pastinya lebih lama dan kami tidak akan tau kabar seseorang dengan cepat seperti kedua orang tua saya dulu yang menjalani hubungan LDR juga."

"Topik yang saya bahas sama suami biasanya seputar rumah tangga, kabar, hari ini ngapain aja, dan anak-anak gimana memastikan semuanya baik-baik saja. Biasanya pertanyaan seperti itu saya tanyakan di waktu pagi dan sore, terkadang pun kalau siang saya suka menanyakan suami saya, "kira-kira sedang makan apa?”

"Anak-anak juga sering saya hubungi lewat mbak asuhnya, kadang mbaknya saya tanya "hari ini menu makanan anakanak apa saja?" Untuk chatting saya dan suami lebih sering 
menggunakan whatsapp, karena tampilannya yang tidak ribet dan juga lebih gampang dipakai, untuk video call ataupun free call, saya pakai whatsapp juga."

"Biasanya setiap pagi sebelum anak-anak berangkat sekolah, saya telpon anak-anak dulu dan video call dulu, biasanya suami yang ngajakin anak-anak untuk video call sama saya. Video call juga seru, meski jauh terasa dekat. Mungkin hal-hal yang lucunya adalah ketika yang kecil pegang handphone dan saya ajak ngobrol, selang beberapa menit dia langsung tertidur. Selebihnya di malam hari atau hari libur dan waktu senggang yang begitu lama, saya lebih memilih untuk menelepon anakanak.4

Dari pemaparan ketiga responden di atas mengenai peran media sosial bagi pasangan suami-istri yang menjalani hubungan jarak jauh dapat diketahuinya ketiganya sepakat bahwa media sosial merupakan suatu alat yang membantu mereka mengatasi hubungan jarak jauh. Kebutuhan manusia sebagai makhluk sosial memang benar adanya dan salah satunya untuk memenuhi kebutuhan bersosialisasi adalah dengan berselancar di dunia maya, menjalin komunikasi dalam wadah jejaring social dan jarak sudah tidak bisa dijadikan sebagai alasan untuk terhentinya kegiatan komunikasi satu sama lain karena di masa kini tidak bisa disamakan dengan masa lalu.

Pada dasarnya, masing-masing memiliki pola komunikasi yang beragam. Mereka melakukan komunikasi via media sosial berupa chat dengan membahas beraneka macam. Pembahasan yang dilakukan rata-rata tentang "keadaan, sedang apa? dan lagi di mana?", tentunya keadaan inilah yang harusnya dilakukan bagi pasangan jarak jauh agar antara suami dan istri tetap saling tahu kondisi masing-masingnya.

Komunikasi merupakan faktor terpenting dalam penyesuaian hubungan perkawinan jarak jauh. Komunikasi antar pribadi dapat terbentuk verbal dan non verbal di mana suatu komunikasi tetap disampaikan dan dikelola secara lengkap jelas dan benar serta tanpa ada kesalapahaman.

4 Koresponden AD, Wawancara, Sejak Mei 2018. 
Fenomena egalitarian marriage di mana suami istri bersamasama bertanggung jawab dalam kesejahteraan keluarga, banyak ditemui masa kini. Suami istri berbagi tugas, tanggung jawab dalam pekerjaan, anak dan hubungan suami istri.5 Perkembangan dunia kerja yang semakin maju menjadikan laki-laki dan perempuan memiliki kesempatan yang sama untuk memiliki dan mengembangkan karir sehingga menghasilkan pasangan dual career, yaitu tetap memiliki karir pribadi dan mencoba menyeimbangkannya dengan kehidupan rumah tangga.6

Hasil wawancara di atas menunjukkan bahwa fenomena dual career tersebut telaksana, di mana seseorang memilih untuk bekerja dan jauh dari keluarga namun tetap menjalani kehidupan rumah tangganya. Bagi pasangan yang telah memiliki anak, adanya media sosial ini sangat membantu dalam kondisi jarak jauh, mereka tetap bersama-sama bertanggung jawab dan berbagi tugas meski dalam keadaan berjauhan.

Pembaharuan dalam teknologi setidaknya sedikit banyak dapat menunjang berbagai macam model komunikasi, dari yang awalnya hanya sebatas surat menyurat, kini mengirim pesan baik dalam bentuk tulisan, suara ataupun video bertatap muka secara langsung, bisa dilsayakan dengan baik. Hal inilah kiranya yang membantu pasangan suami istri jarak jauh agar tetap berkomunikasi secara online lewat media sosial.

Menurut Thompson kualitas komunikasi sangat berperan bagi komitmen perkawinan pasangan karena komitmen perkawinan dibuat dan diciptakan melalui komunikasi dengan pasangan.7 Meski dalam keadaan jarak jaruh ketiga koresponden tersebut mampu memanfaatkan media sosial dengan baik, sebagai sarana dalam berkomunikasi, sehingga adanya komunikasi yang dibentuk pasangan dengan baik akan menghindari degradasi atau penurunan

5Laura E. Berk, Development Through The Lifespan: Dari Dewasa Awal Hingga Menjelang Ajal (Yogyakarta: Pustaka Pelajar, 2012), 70.

6Chiara Saraceno, "Introduction to the Special Issue: Dual Career Couples", Journal: Zeitschrift fur Familienforschung, Vol. 19, No. 3 (2007), 256.

7 M. Thompson dan L.M. Webb, "Commitment Under Construction: A Dyadic and Communicative Model of Marital Commitment", Journal of Family Communication, Vol 4 (2004), 250. 
kepuasan perkawinan dan pasangan akan mempertahankan perkawinannya. Pasangan yang memiliki kepuasan terhadap perkawinan dan pasangan akan sejalan dengan teori Johnson yaitu tentang kepemilikan kepuasan dengan perkawinan yang dijalani.8

\section{Relevansi Media Sosial Terhadap Komunikasi Pasangan Jarak Jauh}

Dalam menjalani hubungan jarak jauh tentu ada baik dan buruknya. Media sosial memberikan energi bagi pasangan yang sedang menjalani masa hubungan jarak jauh. Dari tiga koresponden yang diwawancarai, dua diantaranya memilih untuk menjalani hubungan jarak jauh karena faktor pekerjaan dan salah satunya sedang berkuliah dan meniti karir.

Pasangan dual career tentu memiliki konsekuensi keuntungan dan kerugian dalam perkawinan. Keuntungannya perkawinan di antaranya dukungan emosional ketika salah satu pasangan memiliki masalah pekerjaan dan keadaan ekonomi yang lebih terjamin sedangkan kerugian dari dual career terkadang menjadikan sulitnya untuk mengatur urusan pekerjaan dan keluarga, sehingga dalam keadaan tersebut, memberikan perhatian yang berlebih justru harus dilakukan, dengan cara tetap menjaga pola komunikasi. Hal ini sebagaimana yang dikatakan oleh Rapoport dan Bumstead bahwa:

"In dual-career couples, both spouses pursue separate careers involving work that requires a high degree of commitment and special training with increasing degrees of responbility." 9

"Dalam pasangan dual-career, keduanya terpisah karena pekerjaan sehingga membutuhkan komitmen tinggi dan pelatihan khusus dengan disertai peningkatan tanggung jawab"

Koresponden 1 yaitu IA menyampaikan bagaimana relevansi media sosial terhadap komunikasi pasangan jarak jauh dengan uraian berikut:

8 M. Johnson P., et al., "The Tripartite Nature of Marital Commitment: Personal, Moral, and Structural-Reason to Stay Married", Journal of Marriage and The Family, Vol. 61, No. 1 (Februari, 1999), 161.

9 Angel R. Rhodes, “Working couples", Long-Distance Relationships in Dual-Career Commuter Couples: A Review of Counseling Issues, Vol. 10 No. 4 (2002), 398. 
"Bagaimanapun hubungan LDR ini tetap lebih banyak buruknya daripada tidak LDR. Menggunakan sosmed buat pasangan LDR itu sangat ngebantu, karena cuma sosmed saja media yang murah untuk berkomunikasi apalagi jarak jauh lintas negara kayak kami dengan budget murah dan cepat sampai. Untuk berbagi kebahagiaan di sosmed menurut kami tidak masalah, karena justru ini memudahkan orang lain juga, utamanya memberi kabar pada keluarga tentang keadaan kami. Prihal pamer tentang pasangan, tergantung dari diri sendiri karena yang upload di sosmed itu punya tujuan masingmasing, ada yang memang pamer atau biar eksis di sosmed, nah kalo ini sih biasanya mereka memang punya kesenjangan hidup di real worldnya."

"Begitu juga hambatan yang dialami oleh kami biasanya terkait hal-hal standar. Untuk mengatasinya biasanya saya sih ke kampus pake wifi kampus, kalo istri kadang pinjem kabel LAN, menyesuaikan waktu juga karena kami beda Negara, lainnya sih seringnya kami miskom antara dichat dengan yang diutarakan langsung pastinya beda. Nah ini kadang perlu telpon langsung dan terkadang kalau telponpun belum tentu bisa langsung diangkat karena kami punya kesibukan masingmasing. Kalau video call ekspresi wajah itu betul-betul yang membantu lancarnya komunikasi juga karena memang kalo LDR kan bisanya cuma bertatap via hp."

"Intinya menggunakan media sosial itu harus berhati-hati, tapi apabila media sosial ini hanya seputar chat pribadi dan bersifat komunikasi antar pasangan, keseluruhan sangat membantu."

Koresponden 2 yaitu IS juga menyampaikan mengenai relevansi media sosial terhadap komunikasi pasangan jarak jauh dengan uraian berikut:

"Kalau kami sih Alhamdullilah media sosial buat komunikasi pasangan LDR banyak baiknya dan sangat membantu, soalnya kalo kami tidak tahu informasi satu sama lain itu malah yang bikin hubungan kami memburuk. Sejauh ini kami masih bisa saling mengontrol terutama yang bersifat go public. Sayapun juga yang suka main IG ya sering mengontrol karena di jaman sekarang ini apa-apa serba cepat tersebar, jadi usahakan media 
sosial tetap menjadi wadah yang baik bukan malah mengumbar masalah-masalah internal keluarga."

"Media sosial sangat membantu dalam penyampaian komunikasi terutama saat sedang berjauhan. Kalau misalnya kami masih hidup di jaman surat menyurat tentu itu cukup lama dan perlu waktu menunggu, sedangkan dengan media sosial yang instan ini, kebutuhan apapun yang sifatnya daruratpun bisa dapat terpenuhi. Semisal nantinya saya sakit dan suami dalam keadaan jauh, mau tidak mau media sosial chat ataupun free call ini cepat membantu dalam penyampaian pesan-pesannya."

Koresponden 3 yaitu AD juga menyampaikan mengenai relevansi media sosial terhadap komunikasi pasangan jarak jauh dengan uraian berikut:

"Waktu awal saya sempat cemas karena anak-anak masih kecil dan harus saya tinggal bekerja jauh. Mau tidak mau agar anakanak tetap berkomunikasi dengan ibunya adalah dengan video call secara intens, entah itu di pagi hari setelah bangun tidur atau malam hari sebelum tidur. Saya selalu membiasakan untuk menyempatkan waktu mengobrol dengan anak-anak di sela-sela pekerjaan saya. Ketakutan saya di awal adalah karena nantinya anak harus kontak langsung dengan media sosial dan tahu handphone, pegang gadget, tapi lama kelamaan, ternyata anak-anak mulai memahami sehingga saya merasa media sosial membantu sekali dalam berkomunikasi jarak jauh."

"Hubungan baik atau buruknya sih tergantung orangnya sendiri, gimana dia bisa kontrol. Saya sama suami lebih sering memakai sosmed terutama yang go public untuk bagi-bagi foto anak aja atau acara keluarga gitu aja sih, selebihnya tidak pernah."

"Hambatannya sih buat saya kadang sinyalnya suka ilangilangan kalo di Merauke gitu, lebih-lebih pas kunjungan ke beberapa daerah itu kadang pengennya pulang acara hubungi anak atau suami malah susah sinyal, jadi ya harus sabar, tapi ya kendala kayak gitu itu tidak setiap hari kok."

Dari uraian di atas, ketiga responden memiliki jawaban masing-masing dalam melihat peran media sosial sebagai alat 
komunikasi jarak jauh. IA berpendapat bahwa hubungan yang sebatas media sosial ini tentu tidak sesempurna dengan non verbal, sedangakan IS berpendapat sebaliknya, yaitu justru media sosial ini sangat membantu, setidaknya komunikasi jarak jauh ini tetap bisa dilaksanakan dengan sebaik mungkin jika antara suami dan istri saling membangun pola yang baik.

Adapun AD untuk saat ini merasa tertolong hubungannya dengan adanya media sosial karena mau tidak mau hanya media sosial saja yang mampu mengatasi keadaannya di saat ini. Setidaknya dengan media sosial, beberapa kewajiban sebagai istri ataupun ibu dapat dilakukan oleh AD semaksimal mungkin, dan yang lebih penting pengasuhan anak masih dalam kontrol jarak jauh. Dalam hal ini, anak-anak juga dibiasakan dan dilatih untuk membangun komunikasi dengan orang tuanya ketika saling berjauhan.

\section{Pemenuhan Hak dan Kewajiban Pasangan Jarak Jauh}

Dalam menjalani hubungan jarak jauh, tentu pemenuhan hak dan kewajiban antara keduanya harus tetap dilaksanakan. Bermodalkan media sosial, pasangan suami istri yang menjalani hubungan jarak jauh harus tetap saling menjalankan kewajiban dan mendapatkan hak-haknya.

Teori Sibley mengungkapkan bahwa, komunikasi merupakan salah satu faktor yang mempengaruhi keadaan komitmen perkawinan pada pasangan. Komunikasi memiliki peran yang penting dalam membentuk komitmen perkawinan karena komunikasi dapat membantu pasangan untuk mengetahui kecocokan di antara mereka.10

Koresponden 1 yaitu IA menyampaikan bagaimana antara keduanya tetap menjalankan kewajibannya dan terpenuhi hakhaknya antar pasangan meski dalam keadaan menjalani hubungan jarak jauh dengan paparan berikut:

'Karena kami berdua belum memiliki momongan, setidaknya saya merasa kewajiban saya belum terlalu berat, hanya terfokus

10 D.S. Sibley, "An Exploration Of The Consruction Of Commitment Leading to Marriage" (Thesis--Faculty of the Communication Departmen at Southern Utah University, 2010), 16. 
pada kebutuhan-kebutuhan istri dan urusan rumah. Biasanya untuk kebutuhan rumah tangga, saya dan istri tidak terlalu ambil pusing karena kami memang masih sendiri-sendiri. Setiap bulan kalau ada yang kurang dari istri saat di Ceko, saya langsung transfer seadanya saya karena kami berdua memang masih sama-sama berkuliah dan belum berkerja secara total. Mungkin akan lain cerita dengan yang sudah memiliki momongan. Saya sebagai suami berusaha memenuhi apa yang dibutuhkan istri semampunya, begitupun istri."

"Peranan-peranan istri tidak berubah maupun tergantikan. Kalau berubah secara signifikan sih tidak ada karena kami belum punya momongan, makanya peran yang digantikan paling hanya datang ke acara keluarga istri, sebagai suatu kewajiban untuk datang. Selebihnya urusan rumah kami punya asisten rumah tangga, meski LDR di rumah saya ada "mbak" yang bagian bersih-bersih atau sekedar nyiapin makan atau kadangpun saya beli aja. Kalau istri datang, barulah istri yang nyiapin kadang dibantu sama ART, tapi kalau bersih-bersih tetap ART."

"Urusan hak dan kewajiban ini ada baiknya selalu tetap berjalan dengan baik, meski dalam keadaan jarak jauh. Saya selalu memastikan dan menanyakan apapun itu kepada istri saya karena kami usianya seumuran, setidaknya kami dalam menjalankan rumah tangga layaknya teman sebayaan, tidak menggurui dan belajar bersama-sama."

Selanjutnya koresponden 2 yaitu IS juga menyampaikan bagaimana antara keduanya tetap menjalankan kewajibannya dan terpenuhi hak-haknya antar pasangan meski dalam keadaan menjalani hubungan jarak jauh dengan paparan berikut:

"Sejauh ini meski dalam keadaan jarak jauh kami tetap berkomunikasi dan memaksimalkan media sosial dengan baik. Suami saya jaraknya jauh dengan saya, sehingga saya lebih sering diberi pengertian dan dimomong. Saya selalu berusaha menjalankan kewajiban saya sebagai istri dengan sebaik mungkin karena saya masih kuliah S1, tentunya suami memahami dan tidak mudah cemburu meski saya belajar kelompok dengan lawan jenis. Saya tetap berjaga dan ingat 
kalau saya sudah bersuami. Kewajiban lainnya karena berjauhan, untuk urusan makan saya hanya bisa mengingatkan suami saya, sesekali menanyakan "Sudah makan atau belum?". Begitu pun suami juga selalu melaksanakan kewajibannya, semisal memberi saya nafkah dan kadang pun di sela-sela libur, suami menyempatkan untuk pulang sebentar dan mengajak saya jalan-jalan. Kewajiban-kewajiban kayaknya tidak ada, urusan rumah juga tidak, karena saya masih tinggal di rumah orang tua saya, jadi selebihnya saya bantu-bantu orangtua saya. Hak-hak antara saya dan suami kiranya sudah saling terpenuhi. Kami berusaha membicarakan sebaik mungkin apabila ada hal-hal yang menjanggal. Kalau ngomongin peran yang tergantikan, ada beberapa keadaan yang membuat saya harus gantiin posisi suami tapi hanya sebatas menghadiri acara-acara keluarga saja atau misal ipar yang butuh bantuan jadi saya yang bisa membantu gantiin suami. Selebihnya ya berjalan sesuai apa adanya."

Berbeda halnya dengan koresponden 3 yaitu AD yang menyampaikan bagaimana antara keduanya tetap menjalankan kewajibannya dan terpenuhi hak-haknya antar pasangan meski dalam keadaan menjalani hubungan jarak jauh. Pada kondisi AD ini letak berbedanya adalah pasangan tersebut telah memiliki 2 anak laki-laki sehingga tanggapan penuhan hak dan kewajibannya tentunya berbeda dengan pasangan yang belum memiliki anak yang dapat terlihat dari paparan berikut:

"Saya tetap jalanin peran sebagai ibu ya dengan baik walau memang tidak maksimal, sekarang kan ada video call juga jadi setiap pagi saya pasti suruh mbak buat sambungin ke anakanak, jadi pas pagi anak-anak mau berangkat sekolah atau makan mereka pasti video call dulu sama saya, malam juga video call atau sore sepulangnya saya kerja, kalo suami tetap berkomunikasi via chat atau telpon dan kadang juga video call bareng anak-anak juga."

"Untuk masalah-masalah yang rumit, kadang beberapa disimpan dulu, sampai tunggu sayanya pulang baru dibicarakan, kalau misalnya masalah dikit ya tinggal telpon saja, tapi selebihnya kalau ada urusan rumah tangga ya balik 
lagi semua suami yang bisa atur, saya bantu dikit-dikit misal dalam hal transfer atau tambahin biaya."

"Memang untuk memenuhi kewajiban yang seutuhnya dan tidak bekerja jauh dari anak-anak saat ini cukup sulit, tapi semua balik lagi ke keadaan. Setidaknya dengan jauh sebentar ini, nanti di fase selanjutnya hidup anak-anak juga terjamin. Suami juga tidak ambil pusing dan selalu mendukung. Hakhak antara kami berdua berusaha untuk terpenuhi meski dalam keadaan jarak jauh, begitu juga dengan kewajiban saya sebagai ibu sekaligus istri harus tetap dijalankan. Kalau pun ada waktu libur dan memungkinkan untuk pulang, di saat pulang itu waktu bersama keluarganya dimaksimalkan semaksimal mungkin agar anak-anak dan suami juga senang." "Sebenernya di awal-awal itu sulit, apalagi pas baru punya anak pertama, rasanya ninggal kerja kok kasihan belum lagi ASInya juga, tapi setelah udah besaran dua anakku udah bisa ditinggal dan mengerti kalo bapak ibunya memang sedang bekerja. Dulu awal pas punya anak 1 setiap mau kerja, saya dan suami ngajak dia keliling komplek dulu dan kadangpun sampe dia ketiduran barulah kami berangkat kerja masing-masing. Berhubungku bosku juga baik, jadi saya boleh masuk kantor agak siang karena masih ngurus anak dan suami dulu. Pas yang anak kedua ini jam kerja saya makin padat, 2 anak saya juga sering saya bawa ke rumah orangtu saya karena kami berdua sempat tidak punya mbak pengasuh jadinya bolak-balik Surabaya-Kediri. Pas sudah dapat mbak, jadinya lega apalagi memang yang betul-betul sayang, jadi kami tidak takut untuk menyuruh dia mengasuh anak kami. Kalau di masa sekarang LDRnya sangat jauh, pulangpun tidak bisa setiap akhir pekan, sebulan sekali saja syukur-syukur, jadi ya komunikasinya tetap dijaga lewat seringnya video call. Untungnya juga suami lebih tua dan lebih mengerti juga situasi dan kondisi, jadinya saya berkarirpun tidak dipermasalahkan. Suami juga yang ambil alih mengurus anak di rumah, karena memang suami yang tinggal di rumah bareng mbaknya."

"Kalo peranan saya sebagai istri pasti tergantikan dengan adanya mbak yang bantu dan ngasuh anak di rumah, suamipun 
jadinya makan juga disiapin sama mbaknya, kalo bersih-bersih cuci baju semua juga mbaknya, kadang kalau tidak sempat sarapan suami ya makan di luar. Kalo anak untuk saat ini memang dalam asuhan mbaknya, saya cuma bisa pantau dari jauh dan kalau butuh apa nanti saya transfer uang ke mbaknya atau suami saya yang handle. Beda cerita kalau memang suami yang kerja di luar kota dan tidak menetap di rumah, misal ada kerusakan apa gitu saya minta tolong adik-adik saya yang laki untuk bantu, atau kadang mereka saya mintai tolong untuk menginap nemenin saya dan ponakannya. Untuk hal-hal lain semisal acara di komplek rumah, kalau arisan ibu-ibu gitu, biasanya suami yang bantu setorkan uangnya, kalau acara bapak-bapak kumpul RT RW ya saya ga mungkin menggantikan jadi ya waktu pagi saja diberi info dari pak RTnya."

Menjalani hubungan jarak jauh tentu bukanlah suatu hal yang mudah dan beresiko tinggi tentunya. Hal yang paling tampak dari cerita tentang pengalaman ketiga koresponden di atas adalah ketika menjalani hubungan jarak jauh antara suami istri yang telah memiliki anak dan yang belum memiliki anak dan.

Di sini tampak jelas sebagaimana yang telah diceritakan oleh koresponden ketiga yaitu $\mathrm{AD}$, bahwa ketika pasangan telah memiliki anak dan seorang istri juga menjalani aktifitasnya sebagai wanita karir didukung dengan ditempatkannya di kota yang jauh dari anak-anaknya, maka pemenuhan hak-hak anak tetap diberikan meski secara kontak fisik, hanya suami dan asisten rumah tangga yang mengurusinya. Istri dari jauh tetap menjalankan kewajibannya sebagai ibu dan istri, yaitu dengan cara tetap memantau keadaan di rumah, sering berkomunikasi via telepon, chat ataupun video call agar anak-anak tetap selalu merasa dekat dengan ibunya. Begitu juga suami berkewajiban memberikan support kepada istrinya yang sedang berkarir, selalu mendukung meski dalam keadaan berjauhan.

Berbeda halnya dengan pasangan yang belum memiliki anak, seperti yang diceritakan oleh koresponden IA dan IS, keduanya belum merasakan adanya kesulitan dalam mengerjakan kewajiban maupun memenuhi hak-hak. IA dibantu oleh asisten rumah tangga 
dalam urusan rumah tangganya di saat istri sedang menempuh kuliah di Ceko. Berbeda halnya dengan IS yang tinggal serumah dengan orang tuanya sehingga kewajiban rumah tangganya dilakukan bersamaan dengan kedua orang tuanya. IA merasa telah menjalankan kewajiban terhadap istrinya meski saat ini dalam keadaan berjauhan, begitu juga dengan IS, di mana sang suami selalu berusaha mengerjakan kewajibannya dan sebaliknya.

Hal ini sejalan dengan teori Sibley, bahwa komunikasi merupakan modal utama atau satu faktor yang mempengaruhi keadaan komitmen perkawinan pada pasangan, sehingga ke depannya diharapkan tidak akan ada perpecahan antara keduanya meski dalam keadaan jarak jauh.

Membina keluarga merupakan hal yang pasti terjadi, namun ada beberapa keluarga yang memilih untuk tetap tinggal bersama atau menjalani hubungan pernikahan jarak jauh. Pola hubungan keluarga memiliki dua kategori dalam jurnal Long-Distance Relationships in Dual-Career Commuter Couples: A Review of Counseling Issues yang dikutip oleh Angel R. Rhodes yaitu:

"When commuting families are discussed in the literature, they are usually divided into two categories: those with and those without children living in the home. It is generally agreed that commuting is a more difficult lifestyle for those with children living in the home (Rotter, Barnett, dan Fawcett, 1998)"11

"Ketika keluarga komuter dibahas dalam literatur, biasanya dibagi menjadi dua kategori yaitu mereka dengan dan mereka yang tidak memiliki anak yang tinggal di rumah. Secara umum disepakati bahwa yang lebih sulit adalah adalah bagi mereka dengan anak yang tinggal di rumah. (Rotter, Barnett, dan Fawcett, 1998)"

Dalam isu hukum keluarga Islam, wanita yang berkarir selalu menjadi pembicaraan karena pada zaman dahulu wanita identik dengan bekerja di rumah saja dan mengasuh anak-anak. Akan tetapi, di zaman kini, pria maupun wanita saling bekerja sama

11 J. C. Rotter, et al., "On the Road Again: Dual-Career Commuter Relationships", Long-Distance Relationships in Dual-Career Commuter Couples: A Review of Counseling Issues, Vol. 10, No. 4 (2002), 399. 
untuk memenuhi kebutuhan ekonomi. Dalam bekerja sama ini, beberapa diantaranya dibarengi dengan hubungan jarak jauh meskipun tidak sedikit juga yang tetap tinggal dengan anakanaknya. Dalam kondisi tersebut, media sosial menjadi modal utama bagi suami istri untuk tetap menjaga kualitas hubungan saat sedang berjauhan.

Melihat kejadian AD terkait dengan dual career, menjalani hubungan jarak jauh di sisi lain berkarir dan berumah tangga merupakan suatu pilihan. Yang menjadi kunci utama dari keseluruhan adalah dengan membangun pola komunikasi yang baik dalam lingkup internal keluarga. Kejadian-kejadian berdampak negatif tentunya tidak akan terjadi apabila di antara keduanya saling menjaga komunikasi.

\section{Penutup}

Berangkat dari fenomena antara suami dan istri yang samasama bekerja untuk memenuhi kebutuhan hidup dengan tidak jarang salah satu dari mereka harus ada yang meninggalkan rumah, maka terbentuklah pola rumah tangga dengan model hubungan jarak jauh. Hubungan jarak jauh ini tetap harus terlaksana salah satunya dengan memanfaatkan media sosial agar komitmen keduanya tetap terjaga.

Media sosial sebagai alat untuk melangsungkan komunikasi secara cepat tanpa perlu menunggu lama sangat membantu pola komunikasi pada pasangan suami istri yang terpisah jarak. Modal menjaga komunikasi inilah yang mengantarkan kehidupan berkeluarga yang selalu harmonis dan terjaga meski dalam kondisi hubungan jarak jauh. Dalam inu, pemenuhan terhadap hak dan kewajiban suami-istri tetap bisa dilakukan meskipun tidak dapat semaksimal seperti ketika berhubungan secara langsung.

\section{Daftar Pustaka}

Berk, Laura E. Development Through The Lifespan: Dari Dewasa Awal Hingga Menjelang Ajal. Yogyakarta: Pustaka Pelajar, 2012.

C. Schutz, William. "The Interpersonal Underworld", eds. Palo Alto. California: Science and Behavior Books, 1958.

P., M. Johnson, et al. "The Tripartite Nature of Marital Commitment: Personal, Moral, and Structural-Reason to Stay 
Married". Journal of Marriage and The Family, Vol. 61, No. 1, Februari, 1999.

R. Rhodes, Angel. "Long-Distance Relationships in Dual-Career Commuter Couples: A Review of Counseling Issues". The Family Journal: Counseling And Therapy For Couples And Families, Vol. 10, No. 4, Oktober, 2002.

Ramaraju, S. "Psychological Perspectives On Interpersonal Communication". Journal of Arts, Science \& Commerce, Vol. III, No. 4, Oktober, 2012.

Rapoport, R. dan R. N. Rapoport. Working Couples, eds. J. M. Bumstead. New York: Harper \& Row, 1978.

Rotter, J. C., et al., "On the Road Again: Dual-Career Commuter Relationships". The Family Journal, Vol. 6, No. 1, 1998.

Saraceno, Chiara. "Introduction to the Special Issue: Dual Career Couples". Journal: Zeitschrift fur Familienforschung, Vol. 19, No. 3, 2007.

Sibley, D.S. "An Exploration Of The Consruction Of Commitment Leading to Marriage". Thesis--Faculty of the Communication Departmen at Southern Utah University, 2010.

Thompson, M. dan L. M. Webb. "Commitment Under Construction: A Dyadic and Communicative Model of Marital Commitment". Journal of Family Communication, Vol. 4, No. 4, 2004.

Koresponden AD. Wawancara. Sejak Mei 2018.

Koresponden IA. Wawancara. Sejak April 2018.

Koresponden IS. Wawancara. Sejak Mei 2018. 